\section{Kebijakan Formulasi Tindak Pidana Terhadap Pelaku Usaha yang Tidak Melaksanakan Putusan KPPU yang Sudah Berkekuatan Hukum Tetap (BHT)}

\author{
Oleh: \\ Fitrah Akbar Citrawan ${ }^{1}$
}

\section{Abstract}

Article 44 paragraphs (4) and (5) of Law no. 5 of 1999 regulates that for business actors who do not carry out the KPPU's decisions that have permanent legal force (BHT), KPPU can hand over these business actors to investigators. The provision is unclear, that is, it is not written / stated explicitly, including the categories of acts that can be subject to / threatened with principal or additional crimes as in Articles 48 and 49 of Law No. 5 of 1999. The lack of clarity is related to the issue of formulasi policy which is one of the strategic policies in realizing more rational laws and becomes a guideline for the next functionalization stages, namely the application and execution stages. Formulation of criminal offenses in Article 48 paragraphs (1) and (2) of Law no. 5 of 1999 is interpreted as a wesenschaw offense, which is said to have fulfilled the elements of a criminal offense not only because the act is in accordance with the formulation of a criminal offense but the act is also intended by the legislators, that the business actor and or other party may be convicted if do not carry out what becomes their obligation as in the KPPU Decision which has BHT. Obligations to carry out the business and other parties mentioned, namely carrying out administrative sanctions / actions imposed by KPPU for violating the administration of Law No. 5 of 1999. That also signifies criminal conviction in Article 48 paragraphs (1) and (2) of Law no. 5 of 1999 is ultimum remidium.

Keywords: Formulasi Policy, Business Actors, KPPU Decision.

${ }^{1}$ Mahasiswa Magister IImu Hukum, Unand / Calon Hakim PN Sibuhuan

Email: fitrahakbarc@gmail.com

\begin{abstract}
Abstrak
Pasal 44 ayat (4) dan (5) UU No. 5 Tahun 1999 mengatur bahwa terhadap pelaku usaha yang tidak melaksanakan putusan KPPU yang telah berkuatan hukum tetap (BHT), KPPU dapat menyerahkan pelaku usaha tersebut kepada penyidik. Ketentuan tersebut terdapat ketidakjelasan, yaitu tidak tertulis/tercantum secara tegas termasuk kategori perbuatan yang dapat dikenakan/diancam pidana pokok maupun tambahan sebagaimana dalam Pasal 48 dan 49 UU No. 5 Tahun 1999. Ketidakjelasan tersebut mempunyai keterkaitan dengan persoalan kebijakan formulasi yang merupakan salah satu kebijakan strategis dalam mewujudkan undang-undang yang lebih rasional dan menjadi pedoman bagi tahap-tahap fungsionalisasi berikutnya, yaitu tahap aplikasi dan tahap eksekusi. Formulasi tindak pidana dalam Pasal 48 ayat (1) dan (2) UU No. 5 Tahun 1999 dimaksudkan sebagai delik wesenschaw, yaitu perbuatan dikatakan telah memenuhi unsur tindak pidana tidak hanya karena perbuatan tersebut telah sesuai dengan rumusan tindak pidana tetapi perbuatan tersebut juga dimaksudkan oleh pembentuk undang-undang, bahwa pelaku usaha tersebut dapat dijatuhi pidana apabila tidak melaksanakan apa yang menjadi kewajibannya sebagaimana dalam Putusan KPPU yang telah BHT. Kewajiban pelaku usaha tersebut, yaitu melaksanakan sanksi/tindakan administrasi yang dijatuhkan oleh KPPU atas pelanggaran administrasi UU No. 5 Tahun 1999. Hal tersebut menandakan penjatuhan pidana dalam Pasal 48 ayat (1) dan (2) UU No. 5 Tahun 1999 bersifat ultimum remidium.

Kata Kunci: Kebijakan Formulasi, Pelaku Usaha, Putusan KPPU.
\end{abstract}

\section{PENDAHULUAN}

\section{A. Latar Belakang}

Komisi Pengawas Persaingan Usaha

(KPPU) telah menerima sebanyak 382

perkara sejak tahun 2000 sampai dengan

tahun 2018, dari jumlah tersebut telah

memutus perkara sebanyak 312 yang

diantaranya sebanyak 257 perkara dinyatakan 
bersalah dan dijatuhi sanksi administrasi oleh KPPU. Jenis perkara yang telah diputus oleh KPPU dari 382 perkara tersebut, yaitu:
a. Perkara terkait tender/pengadaan sebanyak 273 perkara $(71 \%)$;
b. Perkara terkait nontender sebanyak 90 perkara (24\%);
c. Perkara terkait merger sebanyak 19 perkara (5\%) (Bahan Paparan KPPU, 2019). ${ }^{2}$
Putusan KPPU yang telah mempunyai kekuatan hukum tetap (BHT) berjumlah 131 perkara sampai dengan tahun 2018. ${ }^{3}$ Memperhatikan ketentuan Pasal 43, 44, dan 45 UU No. 5 Tahun 1999 tentang Larangan Praktik Monopoli dan Persaingan Usaha Tidak Sehat (UU No. 5 Tahun 1999) yang dimaksud dengan putusan KPPU yang telah BHT, yaitu:

a. Putusan KPPU yang oleh Terlapor (pelaku usaha) dalam jangka waktu 14 hari setelah menerima pemberitahuan putusan tersebut tidak diajukan upaya hukum keberatan ke Pengadilan Negeri;

b. Putusan KPPU yang telah diputus sampai tingkat Kasasi oleh Mahkamah Agung. Dengan kata lain suatu putusan memperoleh kekuatan hukum yang pasti atau tetap (inkracht van gewisjde) apabila tidak ada lagi upaya hukum biasa yang tersedia.

Pasal 44 ayat (1) UU No. 5 Tahun 1999 mengatur bahwa dalam waktu 30 (tiga puluh) hari sejak pelaku usaha menerima pemberitahuan putusan KPPU, pelaku usaha wajib melaksanakan putusan tersebut dan menyampaikan laporan pelaksanaannya kepada KPPU. Guntur Syahputra Saragih selaku Komisioner KPPU mengatakan bahwa dalam pelaksanaannya masih terdapat pelaku usaha yang tidak kooperatif dalam menjalankan putusan KPPU yang telah

\footnotetext{
${ }^{2}$ Bahan Paparan oleh Komisi Pengawas Persaingan Usaha disampaikan dalam Diklat III Program Pendidikan dan Pelatihan Calon Hakim Terpadu Angkatan III Gel. I tanggal 4 September 2019 di Badiklat Litbang Kumdil Mahkamah Agung, Megamendung.

${ }^{3}$ Komisi Pengawas Persaingan Usaha, Laporan Tahunan KPPU Tahun 2018, hal. 29.
}

berkuatan hukum tetap. ${ }^{4}$ Denda yang dijatuhkan kepada pelaku usaha berdasarkan Putusan KPPU selama kurun waktu tahun 2000 sampai dengan tahun 2018 sebesar Rp526.546.617.859,00, jumlah denda yang sudah dibayar sebesar Rp364.316.724.995, sedangkan denda yang belum dibayar oleh pelaku usaha sebesar $\operatorname{Rp} 162.239 .895 .530 .^{5}$

Langkah yang dilakukan KPPU dalam menghadapi pelaku usaha yang tidak menjalankan putusan KPPU yang sudah BHT, yaitu melalui pihak ketiga untuk melakukan penagihan, upaya persuasif, teguran tertulis, dan publikasi media. Selain itu, terhadap pelaku usaha tersebut KPPU dapat meminta penetapan eksekusi dari Pengadilan Negeri atau pelaku usaha tersebut diproses pidana. ${ }^{6}$ Menurut Yudi Hidayat selaku Komisioner KPPU bahwa sampai pada September 2019 KPPU belum memproses ke ranah pidana terhadap pelaku usaha yang tidak melaksanakan putusan yang sudah BHT. ${ }^{7}$ Berdasarkan Pasal 44 ayat (4) dan (5) UU No. 5 Tahun 1999, bahwa terhadap putusan KPPU yang telah BHT tidak dijalankan oleh pelaku usaha, KPPU menyerahkan putusan tersebut kepada penyidik untuk dilakukan penyidikan sesuai dengan ketentuan peraturan perundang-undangan yang berlaku. Putusan KPPU tersebut merupakan bukti permulaan yang cukup bagi penyidik untuk melakukan penyidikan.

\footnotetext{
${ }^{4}$ Guntur Syahputra Saragih, Update Eksekusi Putusan KPPU, tersedia pada http://www.kppu.go.id/id//blog/2019/07/updateeksekusi-putusan-kppu/, diakses pada 6 September 2019.

${ }^{5}$ Komisi Pengawas Persaingan Usaha, Laporan Tahunan KPPU Tahun 2018,

${ }^{6}$ Guntur Syahputra Saragih, Loc. Cit.

7Yudi Hidayat, Pemaparan dalam Diklat III Program Pendidikan dan Pelatihan Calon Hakim Terpadu Angkatan III Gel. I tanggal 4 September 2019 di Badiklat Litbang Kumdil Mahkamah Agung, Megamendung.
} 
Media Komunikasi dan Informasi Hukum dan Masyarakat

KPPU memproses ke ranah pidana terhadap pelaku usaha yang tidak melaksanakan putusan KPPU yang sudah BTH mempunyai keterkaitan dengan pendapat Eman Sulaeman, yaitu bahwa terhadap UU No. 5 Tahun 1999 termasuk peraturan perundangan dalam bidang hukum administrasi yang juga mengatur ketentuan pidana. ${ }^{8}$ Peristilahan penggunaan hukum pidana dalam bidang hukum administrasi oleh Barda Nawawi Arief dan Sudarto disebut sebagai hukum pidana administrasi. ${ }^{9}$ Hukum pidana dalam hal ini digunakan sebagai sarana untuk meningkatkan rasa tanggungjawab negara dalam rangka mengelola kehidupan masyarakat modern yang semakin kompleks. ${ }^{10}$

Pasal 44 ayat (4) dan (5) UU No. 5 Tahun 1999 tersebut terdapat ketidakjelasan, yaitu perbuatan pelaku usaha yang tidak melaksanakan putusan KPPU yang sudah BHT tidak tertulis/tercantum secara tegas termasuk kategori perbuatan yang dapat dikenakan/diancam pidana pokok maupun tambahan sebagaimana dalam Pasal 48 dan 49 UU No. 5 Tahun 1999. Hal tersebut senada dengan pendapat Mudzakkir bahwa "dalam UU No. 5 Tahun 1999 terdapat ketidakjelasan mengenai perbuatan apa saja yang dikategorikan sebagai tindak pidana. Hal tersebut berbahaya karena standar keadilan

${ }^{8}$ Eman Sulaeman (2014). Kebijakan Penggunaan Sanksi Pidana dalam Perundang-Undangan Hukum Administrasi. Wahana Akademika IAIN Walisongo Semarang, 1(1), 135-148. doi: http://dx.doi.org/10.21580/wa.v1i1.806.

${ }^{9}$ Barda Nawawi Arief, Kapita Selekta Hukum Pidana, Bandung. PT Citra Aditya Bakti, 2003, hal.14 dan Sudarto, Kapita Selekta Hukum Pidana, Cetakan II, Alumni, Bandung, 1986, hal. 65.

${ }^{10}$ Muladi, Proyeksi Hukum Pidana Materiil Indonesia di Masa Datang, Naskah Pidato Pengukuhan, Diucapkan pada Peresmian Penerimaan Jabatan Guru Besar Dalam IImu Hukum pada Fakultas Hukum Universitas Diponegoro, Semarang, 1990, hal. 149. menjadi tidak terjamin". ${ }^{11}$

Pasal 48 UU No. 5 Tahun 1999 mengatur mengenai perbuatan-perbuatan yang dapat dijatuhkan pidana pokok yaitu sebagai berikut:

1) Pelanggaran terhadap ketentuan Pasal 4 (oligopoli), Pasal 9 sampai dengan Pasal 14 (pembagian wilayah, pemboikotan, kartel, trust, oligopsoni, integrasi vertikal), Pasal 16 sampai dengan Pasal 19 (perjanjian dengan pihak luar negeri, monopoli, monopsoni, penguasaan pasar), Pasal 25 (posisi dominan), Pasal 27 (pemilihan saham), dan Pasal 28 (penggabungan, peleburan, pengambilalihan) diancam pidana denda serendah-rendahnya Rp 25.000.000.000,00 (dua puluh lima miliar rupiah) dan setinggi-tingginya $R p$ 100.000.000.000,00 (seratus miliar rupiah), atau pidana kurungan pengganti denda selama-lamanya 6 (enam) bulan.

2) Pelanggaran terhadap ketentuan Pasal 5 sampai dengan Pasal 8 (penetapan harga), Pasal 15 (perjanjian tertutup), Pasal 20 sampai dengan Pasal 24 (Penguasaan pasar, persengkokolan, dll), dan Pasal 26 (jabatan rangkap) Undangundang ini diancam pidana denda serendah-rendahnya Rp 5.000.000.000,00 ( lima miliar rupiah) dan setinggi-tingginya Rp 25.000.000.000,00 (dua puluh lima miliar rupiah), atau pidana kurungan pengganti denda selama-lamanya 5 (lima) bulan.

3) Pelanggaran terhadap ketentuan Pasal 41 Undang-undang ini (penghalangan proses pemeriksaan di KPPU) diancam pidana denda serendah-rendahnya $\mathrm{Rp}$ 1.000.000.000,00 (satu miliar rupiah) dan setinggi-tingginya $\mathrm{Rp} \quad 5.000 .000 .000,00$ (lima miliar rupiah), atau pidana kurungan pengganti denda selama-lamanya 3 (tiga) bulan.

Pasal 49 UU No. 5 Tahun 1999 mengatur mengenai pidana tambahan yaitu:

a. pencabutan izin usaha; atau

b. larangan kepada pelaku usaha yang telah terbukti melakukan pelanggaran terhadap

\footnotetext{
${ }^{11}$ Mudzakkir, Mempersoalkan Sanksi Pidana dalam Hukum Persaingan Usaha: Pengaturan sanksi pidana di dalam UU Anti Monopoli dinilai tak memenuhi ketentuan pidana, tersedia pada https://www. hukumonline.com/berita/baca/hol21865/ mempersoalkan-sanksi-pidana-dalam-hukumpersaingan-usahal, diakses pada 7September 2019.
} 
undang-undang ini untuk menduduki jabatan direksi atau komisaris sekurangkurangnya 2 (dua) tahun dan selamalamanya 5 (lima) tahun; atau

c. penghentian kegiatan atau tindakan tertentu yang menyebabkan timbulnya kerugian pada pihak lain.

Perbuatan pelaku usaha yang tidak melaksanakan putusan KPPU yang sudah BHT sebagaimana Pasal 44 ayat (4) UU No. 5 Tahun 1999, apabila dilihat pada Pasal 48 dan 49 di atas tidak termasuk sebagai tindak pidana. Hal tersebut akan menimbulkan ketidakjelasan dalam penegakan hukum persaingan usaha. Ketidakjelasan tersebut mempunyai keterkaitan dengan persoalan kebijakan kriminal. Sudarto berpendapat bahwa "apabila hukum pidana hendak dilibatkan dalam usaha mengatasi segi-segi negatif dari perkembangan masyarakat/modernisasi (antara lain penanggulangan kejahatan), maka hendaknya dilihat dalam hubungan keseluruhan kebijakan/politik kriminal dan ini pun harus merupakan bagian integral dari rencana pembangunan nasional" Barda Nawawi Arief dengan mengutip pendapat Marc Ancel memaknai kebijakan kriminal, yaitu suatu usaha rasional dari masyarakat untuk menanggulangi kejahatan. ${ }^{12}$ Muladi dan Barda Nawawi Arief berpendapat bahwa kebijakan kriminal dapat menggunakan sarana penal (hukum pidana) dan non penal. ${ }^{13}$ Kebijakan kriminal dengan sarana penal yang fungsionalnya/ operasionalisasinya melalui beberapa tahapan, yaitu formulasi (kebijakan legislatif/formulasi), aplikasi (kebijakan yudikatif/yudicial), dan eksekusi (kebijakan

${ }^{12}$ Barda Nawawi Arief, Bunga Rampai Kebijakan Hukum Pidana, Cetakan Kedua edisi Revisi, PT Citra Aditya Bakti, Bandung, 2002, hal. 3-4.

${ }^{13}$ Muladi dan Barda Nawawi Arief, Teori-Teori dan Kebijakan Pidana, Bandung, Alumni, 1998, hal. 158. eksekusi/administratif). ${ }^{14}$

Pengaturan ketentuan pidana dalam perundang-undangan yang bersifat administrasi dalam hal ini Pasal 44 ayat (4) dan (5) dan Pasal 48 Undang-Undang Nomor 5 Tahun 1999 perlu untuk dikaji lebih dalam lagi terutama dalam sisi kebijakan kriminal agar dapat tercapai tujuan pengaturan ketentuan pidana itu sendiri. Pengkajian sendiri hendaknya dimulai pada saat tahapan formulasi/pembuatan undang-undang yang merupakan salah satu kebijakan strategis dalam mewujudkan undang-undang yang lebih rasional. Selain itu, tahap formulasi merupakan dasar, landasan dan pedoman bagi tahap-tahap fungsionalisasi berikutnya, yaitu tahap aplikasi dan tahap eksekusi.

\section{B. Perumusan Masalah}

Adapun yang menjadi permasalahan dalam tulisan ini, yaitu "bagaimana kebijakan formulasi tindak pidana terhadap pelaku usaha yang tidak melaksanakan putusan Komisi Pengawas Persaingan Usaha (KPPU) yang berkuatan hukum tetap dalam UU No. 5 Tahun 1999?.

\section{Metode Penelitian}

Metode penelitian dalam penelitian ini adalah yuridis normatif dengan menggunakan pendekatan perundang-undangan (statute approach), pendekatan analitis (analytical approach), dan pendekatan historis (historical approach). Sifat penelitian yang digunakan dalam penelitian ini adalah deskriptif analitis.

\section{PEMBAHASAN}

Pasal 44 ayat (4) dan (5) UU No. 5 Tahun 1999 mengatur bahwa apabila putusan

\footnotetext{
${ }^{14}$ Hambali Thalib, Sanksi Pemidanaan dalam Konflik Pertanahan, Kencana Prenada Media Group, Jakarta, 2012, hal. 14-15.
} 


\section{JURNAL HUKUM KAIDAH}

\section{Media Komunikasi dan Informasi Hukum dan Masyarakat}

KPPU yang telah berkuatan hukum tetap tidak dijalankan oleh pelaku usaha, KPPU menyerahkan putusan tersebut kepada penyidik untuk dilakukan penyidikan sesuai dengan ketentuan peraturan perundangundangan yang berlaku. Putusan KPPU tersebut merupakan bukti permulaan yang cukup bagi penyidik untuk melakukan penyidikan.

DPR dan Pemerintah dalam Rapat Pembahasan Daftar Inventaris Masalah (DIM) Perancangan UU No. 5 Tahun 1999 memperdebatkan mengenai instansi yang bewenang sebagai penyidik sebagaimana dalam Pasal 44 ayat (4) UU No. 5 Tahun 1999 tersebut. Rahardi Ramelan selaku Menperindag (Menteri Perindustrian dan Perdagangan) tahun 1998 dalam rapat tersebut berpendapat bahwa penyidik ialah para anggota profesional ataupun ahli profesional yang ditunjuk oleh KPPU. Jadi tidak perlu lagi penunjukan kepada penyidik lain. Contoh pada Departmen Perindustrian dan Perdagangan bahwa penyidiknya ialah seorang PNS yang dididik oleh kepolisian. Penyidik semacam ini dimungkinkan. Erwin Syahril selaku Anggota DPR tahun 1998 menanggapi pernyataan dari Rahardi Ramelan bahwa "KPPU bukan penyidik, sebatas nanti keputusan tidak dilaksanakan, maka diserahkan kepada badan yang bisa melakukan tindakan-tindakan lebih jauh terhadap tingkah laku yang telah menimbulkan kerugian atau tingkah laku yang dianggap monopoli. Penyidik sudah ditentukan di dalam UU (KUHAP)". 15

Keputusan Rapat Panitia Kerja ke-8

\footnotetext{
${ }^{15}$ Risalah Rapat Proses Pembahasan Rancangan Undang-Undang tentang Larangan Praktik Monopoli dan Persaingan Usaha Tidak Sehat, Sekretariat Jenderal DPR RI, Jakarta, 1999, hal. 82, 222, 664665 , dan 784
}

Perancangan UU No. 5 Tahun 1999 tanggal 11 Januari 1999 diperoleh kesepakatan bahwa KPPU tidak mempunyai wewenang melakukan penyidikan sebagaimana dalam Pasal 44 ayat (4) UU No. 5 Tahun $1999^{16}$. Hal tersebut juga dapat dilihat dalam Pasal 36 UU No. 5 Tahun 1999 yang mengatur mengenai wewenang KPPU yang sebatas sebagai berikut:

a. menerima laporan dari masyarakat dan atau dari pelaku usaha tentang dugaan terjadinya praktek monopoli dan atau persaingan usaha tidak sehat;

b. melakukan penelitian tentang dugaan adanya kegiatan usaha dan atau tindakan pelaku usaha yang dapat mengakibatkan terjadinya praktek monopoli dan atau persaingan usaha tidak sehat;

c. melakukan penyelidikan dan atau pemeriksaan terhadap kasus dugaan praktek monopoli dan atau persaingan usaha tidak sehat yang dilaporkan oleh masyarakat atau oleh pelaku usaha atau yang ditemukan oleh Komisi sebagai hasil penelitiannya;

d. menyimpulkan hasil penyelidikan dan atau pemeriksaan tentang ada atau tidak adanya praktek monopoli dan atau persaingan usaha tidak sehat;

e. memanggil pelaku usaha yang diduga telah melakukan pelanggaran terhadap ketentuan undang-undang ini;

f. memanggil dan menghadirkan saksi, saksi ahli, dan setiap orang yang dianggap mengetahui pelanggaran terhadap ketentuan undang-undang ini;

g. meminta bantuan penyidik untuk menghadirkan pelaku usaha, saksi, saksi ahli, atau setiap orang sebagaimana dimaksud huruf e dan huruf $f$, yang tidak bersedia memenuhi panggilan Komisi;

h. meminta keterangan dari instansi Pemerintah dalam kaitannya dengan penyelidikan dan atau pemeriksaan terhadap pelaku usaha yang melanggar ketentuan undang-undang ini;

i. mendapatkan, meneliti, dan atau menilai surat, dokumen, atau alat bukti lain guna penyelidikan dan atau pemeriksaan;

${ }^{16} /$ bid., hal. 1176-1179 dan 1206. Jurnal Hukum KAIDAH 
j. memutuskan dan menetapkan ada atau tidak adanya kerugian di pihak pelaku usaha lain atau masyarakat;

k. memberitahukan putusan Komisi kepada pelaku usaha yang diduga melakukan praktek monopoli dan atau persaingan usaha tidak sehat;

I. menjatuhkan sanksi berupa tindakan administratif kepada pelaku usaha yang melanggar ketentuan Undang-undang ini.

KPPU berdasarkan Pasal 36 huruf (c), (d), (h), dan (i) UU No. 5 Tahun 1999 di atas mempunyai wewenang untuk melakukan penyelidikan. Namun, berdasarkan amar Putusan Mahkamah Konstitusi Nomor: 85/PUU-XIV/2016 bahwa frasa "penyelidikan" dalam Pasal tersebut dimaknai dengan "pengumpulan alat bukti sebagai bahan pemeriksaan". Pasal 39 sampai dengan Pasal 45 UU No. 5 Tahun 1999 apabila dihubungkan dengan Peraturan Komisi Pengawas Persaingan Usaha Nomor 1 Tahun 2019 Tentang Tata Cara Penanganan Perkara Praktik Monopoli dan Persaingan Usaha Tidak Sehat (Perkom No. 1 Tahun 2019), maka pengertian pemeriksaan adalah serangkaian kegiatan yang dilakukan oleh Majelis KPPU yang dibantu oleh Panitera meliputi sebagai berikut:

1. Pemeriksaan pendahuluan adalah serangkaian kegiatan yang dilakukan oleh Majelis KPPU terhadap laporan dugaan pelanggaran untuk menetapkan perubahan perilaku, menjatuhkan Putusan atau menyimpulkan perlu atau tidak perlu dilakukan pemeriksaan lanjutan.

2. Pemeriksaan lanjutan adalah serangkaian kegiatan yang dilakukan oleh Majelis KPPU untuk membuktikan ada atau tidak adanya pelanggaran.

3. Pemeriksaan tambahan dilakukan oleh Majelis KPPU yang memutus Putusan Komisi yang diajukan keberatan oleh Terlapor.

Dengan demikian berdasarkan Putusan

Mahkamah Konstitusi Nomor: 85/PUU-
XIV/2016, Pasal 39 sampai dengan Pasal 45 UU No. 5 Tahun 1999, dan Perkom No. 1 Tahun 2019 bahwa wewenang penyelidikan KPPU dimaknai serangkaian kegiatan yang dilakukan oleh KPPU untuk mendapatkan bukti yang cukup sebagai bahan pemeriksaaan dalam lingkup penegakan hukum administrasi UU No. 5 Tahun 1999. Putusan Mahkamah Konstitusi tersebut juga mempertimbangkan terkait pemaknaan penyelidikan, penyidik dan penyidikan dalam UU No. 5 Tahun 1999, yaitu:

Pasal 44 ayat (4) UU 5 Tahun 1999 baru dapat dilaksanakan apabila putusan KPPU yang berisi sanksi administrasi kepada pelaku usaha tidak dijalankan oleh pelaku usaha dimaksud dan apabila pelaku usaha tersebut tidak mengajukan keberatan kepada Pengadilan Negeri terhadap putusan KPPU dimaksud. Dalam hal terjadinya demikian, putusan KPPU selanjutnya diserahkan kepada penyidik untuk kemudian dilakukan penyidikan. Putusan tersebut harus sudah berkekuatan hukum tetap sebelum diserahkan kepada penyidik. Dalam tahap penyidikan inilah berlalu ketentuan KUHAP dan dalam keadaan yang demikian penyidik tidak kemudian serta merta kehilangan kewenangan untuk melakukan penyelidikan apabila hasil pemeriksaan yang telah diserahkan dari KPPU tersebut masih dipandang belum mencukupi. Berbeda dengan penyelidikan, penyidikan merupakan serangkaian tindakan penyidik dalam hal dan menurut cara yang diatur dalam KUHAP untuk mencari serta mengumpulkan bukti yang dengan bukti itu membuat terang tentang tindak pidana yang terjadi dan guna menemukan tersangkanya. Dengan kata lain proses dari penyelidikan dan pelimpahan berkas perkara sampai kepada persidangan pengadilan adalah sebuah rangkaian proses yang terakumulasi dan tidak terputus dan hal tersebut termasuk dalam bingkai penegakan hukum pidana dan dalam konteks pro justitia.

Putusan Mahkamah Konstitusi Nomor: 85/PUU-XIV/2016 tersebut telah memberikan kejelasan tentang penyelidik, penyelidikan, penyidik dan penyidikan dalam Pasal 44 ayat Jurnal Hukum KAIDAH 
(4) UU 5 Tahun 1999 merupakan segaimana dalam KUHAP, yaitu:

1. Penyidik adalah pejabat polisi negara Republik Indonesia atau pejabat pegawai negeri sipil tertentu yang diberi wewenang khusus oleh undang-undang untuk melakukan penyidikan (Pasal 1 ayat (1) KUHAP).

2. Penyidikan adalah serangkaian tindakan penyidik dalam hal dan menurut cara yang diatur dalam undang-undang ini untuk mencari serta mengumpulkan bukti yang dengan bukti itu membuat terang tentang tindak pidana yang terjadi dan guna menemukan tersangkanya (Pasal 1 ayat (2) KUHAP).

3. Penyelidik adalah pejabat polisi negara Republik Indonesia yang diberi wewenang oleh undang-undang ini untuk melakukan penyelidikan (Pasal 1 ayat (4) KUHAP).

4. Penyelidikan merupakan serangkaian tindakan penyelidik untuk mencari dan menemukan suatu peristiwa yang diduga sebagai tindak pidana guna menentukan dapat atau tidaknya dilakukan penyidikan menurut cara yang diatur dalam undangundang ini (Pasal 1 angka (5) KUHAP).

Pasal 44 ayat (4) UU 5 Tahun 1999 mengatur bahwa Putusan KPPU sudah BHT yang tidak dilaksanakan oleh pelaku usaha merupakan bukti permulaan yang cukup bagi penyidik untuk melakukan penyidikan. Refly Harun berpendapat bahwa walaupun Putusan KPPU tersebut merupakan bukti permulaan yang cukup, maka tidak serta merta menghilangan indepedensi penyidik dalam penegakan hukum (pro justitia), setidaknya bukti permulaan ini menjadi titik awal (starting point) penyidik dalam menemukan/mengumpulkan alat bukti tambahan dan menentukan siapa tersangkanya. Mahkamah Konstitusi berpendapat senada dengan Refly Harun bahwa penyidik tidak kemudian serta merta kehilangan kewenangan untuk melakukan penyelidikan apabila Putusan KPPU yang telah diserahkan tersebut masih dipandang belum mencukupi. Mahkamah Konstitusi menafsirkan bahwa "bukti permulaan yang cukup" merupakan minimal dua alat bukti yang termuat dalam Pasal 184 KUHAP, yaitu keterangan saksi, keterangan ahli, surat, petunjuk, dan keterangan terdakwa. ${ }^{17}$

Soedjono Dirdjosisworo berpendapat mengenai pentingnya penyelidikan dan penyelidikan dalam sistem peradilan pidana, yaitu:

Pemeriksaan penyidikan yang didahului dengan tindakan penyelidikan adalah serangkaian upaya penting dalam memberi kebenaran sejati tentang adanya persangkaan dilakukannya tindak pidana, yang mempunyai arti penting dan mewarnai jalannya pemeriksaan di muka persidangan serta pada gilirannya benarbenar mampu menetapkan mempidana (menghukum) sibersalah. ${ }^{18}$

Pasal 44 ayat (4) dan (5) UU 5 Tahun 1999 bukan merupakan ketentuan yang mengatur mengenai rumusan delik/tindak pidana terhadap pelaku usaha yang tidak melaksanakan putusan KPPU yang BHT, melainkan pasal tersebut mengatur prosedur atau mekanisme sistem peradilan pidana dalam rangka proses penegakan hukum larangan praktik monopoli dan persaingan usaha dengan menggunakan hukum pidana. Adami Chazawi menyatakan bahwa berdasarkan perundang-undangan yang ada maupun dalam berbagai literatur hukum istilah starfbaar feit diterjemahkan sebagai tindak pidana, peristiwa pidana, delik, pelanggaran pidana, perbuatan yang boleh dihukum, perbuatan yang dapat dihukum, dan tindak pidana. ${ }^{19}$ Sudarto berpendapat bahwa pemakaian istilah yang berlainan dalam

\footnotetext{
${ }^{17}$ Mahkamah Konstitusi Republik Indonesia, Putusan Nomor: 85/PUU-XIV/2016, hal. 175-176, 195 dan Putusan Nomor: 21/PUU-XII/2014, hal. 109.

${ }^{18}$ Soedjono Dirdjosisworo, Pemeriksaan Pendahuluan menurut KUHAP, Alumni, Bandung, 1982, hal. 4.

${ }^{19}$ Adami Chazawi, Pelajaran Hukum Pidana, Rajagrafindo, Jakarta, 2002, hal. 67-68.
} 
penerjemahan starfbaar feit tidak menjadi soal, asal diketahui apa yang dimaksudkan dan dalam hal ini yang penting adalah isi dan pengertian. $^{20}$ Pembentuk undang-undang mengartikan starfbaar feit sebagai tindak pidana. Pasal 12 ayat (1) RUU KUHP September 2019 memberikan pengertian tindak pidana, yaitu perbuatan yang oleh peraturan perundang-undangan diancam dengan sanksi pidana dan/atau tindakan.

Moeljatno membedakan dengan tegas "dapat dipidananya perbuatan" (de strafbaarheid van het feit atau het verboden zijr van het feit) dan "dapat dipidanakannya orangnya" (strafbaarheid van de persoon), sejalan dengan ini Moeljatno memisahkan antara pengertian "tindak pidana" (criminal act) dan "pertanggung jawab pidana" (criminal reponsibility atau criminal liability). Oleh karena hal tersebut dipisahkan, maka pengertian tindak pidana tidak meliputi pertanggungjawaban pidana. Padangan Moeljatno dapat disebut padangan yang dualictic mengenai tindak pidana. Padangan ini adalah penyimpangan dari padangan yang disebut oleh Moeljatno sebagai padangan yang monictic, yang dianggap kuno. Padangan monictic melihat keseluruhan syarat untuk adanya pidana itu kesemuanya merupakan dari perbuatan. ${ }^{21}$

Eddy O.S. Hiariej berpendapat mengenai pandangan dualictic dari segi pembuktian, yaitu:

Pandangan dualictic yang memisahkan antara tindak pidana dan pertanggungjawaban pidana sesungguhnya untuk mempermudah penuntutan terhadap seseorang yang telah melakukan suatu tindak pidana dalam hal pembuktian. Di depan sidang pengadilan, biasanya pembuktian

${ }^{20}$ Sudarto, Hukum Pidana I, Edisi Revisi, Yayasan Sudarto, Semarang, 2013, hal. 65.

${ }^{21}$ lbid., hal. 66-67. dimulai dengan adanya tindak pidana, baru kemudian apakah tindak pidana yang telah dilakukan dapat tidaknya dimintakan pertanggungjawaban terhadap terdakwa yang sedang diadili. ${ }^{22}$

Adami Chazawi menyatakan bahwa "dalam praktik hukum untuk memidana terdakwa yang dihadapkan ke sidang pengadilan dengan dakwaan melakukan tindak pidana tertentu, maka disyaratkan harus terpenuhinya semua unsur yang terdapat dalam tindak pidana tersebut". ${ }^{23}$ Hal tersebut senada dengan pendapat Sudarto bahwa suatu perbuatan dapat dikatakan memenuhi rumusan tindak pidana dalam undang-undang apabila sebagai berikut:

Perbuatan konkrit dari sipembuat itu harus mempunyai sifat-sifat atau ciri-ciri dari tindak pidana itu sebagaimana secara abstrak disebutkan dalam undang-undang. Perbuatan itu harus masuk dalam rumusan delik itu. Dalam rumusan itu undang-undang melukiskan perbuatan yang dimaksud secara skematis, tidak secara kongkrit. ${ }^{24}$

Van Bemmelen dan Van Hattum juga berpendapat bahwa:

“.........delictsomschrijvingen niet meer zijn dan uit hun verband gerukte fragmenten. De wetgever kan niet anders dam schematisch te werk gaan. Concrete gedragingen welke onder een delictsomschrijvingen vallen behoren tot een groep van door de wet in het algemeen strafbaar gestelde gedragingen. Door de schematische, fragmentarische omschrijving vallen biinnen die groep ook een antall gedragingen, welke daar niet thuis behoren, omdat zij niet onbehoorlijk, niet verwerpelijk, niet laakbaar, niet ongeoorloofd, niet wederechtelijk zijn, doch integendeel behoorlijk, wenselijk, te prijzen, geoorloofd en rechmatig" (rumusan-rumusan delik itu hanyalah fragmen-fragmen yang dipisah-pisahkan dari hubungannya. Pembuat undangundang tidak dapat berbuat lain daripada

\footnotetext{
${ }^{22}$ Eddy O.S. Hiariej, Prinsip-Prinsip Hukum Pidana......Op.Cit., hal. 125.

${ }^{23}$ Adami Chazawi, Pelajaran Hukum.........Op. Cit., hal. 77.

${ }^{24}$ Sudarto, Hukum Pidana.......Op.Cit., hal. 87. 


\section{Media Komunikasi dan Informasi Hukum dan Masyarakat}

hanya secara skematis saja. Perbuatanperbuatan kongkret yang masuk dalam rumusan delik adalah merupakan sekumpulan perbuatan-perbuatan yang pada umumnya diancam dengan pidana. Karena rumusan yang fragmen dan skematis tadi maka di sana semestinya, karena tidaklah merupakan perbuatan yang tercela atau tidak dibenarkan). ${ }^{25}$

Eddy O.S. Hiariej berpendapat bahwa rumusan tindak pidana tersebut mempunyai dua fungsi, yaitu sebagai pengejawantahan asas legalitas dan sebagai unjuk bukti dalam konteks hukum acara pidana. Selain itu, rumusan delik yang berisi unsur-unsur delik hanya dapat diketahui dengan membaca pasal-pasal yang berisi suatu ketentuan pidana. $^{26}$ UU No. 5 Tahun 1999 mengatur ketentuan pidana dalam Pasal 48 (pidana pokok) dan Pasal 49 (pidana tambahan). Pasal 48 UU No. 5 Tahun 1999 mengatur bahwa:

1. Pelanggaran terhadap ketentuan Pasal 4, Pasal 9 sampai dengan Pasal 14, Pasal 16 sampai dengan Pasal 19, Pasal 25, Pasal 27, dan Pasal 28 diancam pidana denda serendahrendahnya $\mathrm{Rp} 25.000 .000 .000,00$ (dua puluh lima miliar rupiah) dan setinggitingginya $\mathrm{Rp} \quad 100.000 .000 .000,00$ (seratus miliar rupiah), atau pidana kurungan pengganti denda selamalamanya 6 (enam) bulan.

2. Pelanggaran terhadap ketentuan Pasal 5 sampai dengan Pasal 8, Pasal 15, Pasal 20 sampai dengan Pasal 24, dan Pasal 26 Undang-undang ini diancam pidana denda serendah-rendahnya $\mathrm{Rp}$ 5.000.000.000,00 ( lima miliar rupiah) dan setinggi-tingginya $\mathrm{Rp}$ 25.000.000.000,00 (dua puluh lima miliar rupiah), atau pidana kurungan pengganti denda selama-lamanya 5 (lima) bulan.

3. Pelanggaran terhadap ketentuan Pasal 41 Undang-undang ini diancam pidana denda serendah-rendahnya $\mathrm{Rp}$

\footnotetext{
${ }^{25}$ Eddy O.S. Hiariej, Prinsip-Prinsip Hukum .....Op.Cit., hal. 130.

${ }^{26}$ Ibid., hal. 130-131.
}

\begin{abstract}
1.000.000.000,00 (satu miliar rupiah) dan setinggi-tingginya Rp 5.000.000.000,00 (lima miliar rupiah), atau pidana kurungan pengganti denda selama-lamanya 3 (tiga) bulan.
\end{abstract}

Pasal 48 ayat (1), (2), dan (3) di atas apabila dilihat secara letterlijk, maka rumusan tindak pidananya sebagai berikut:

1. Dapat dipidana sebagaimana dalam Pasal 48 ayat (1), apabila pelaku usaha dan atau pihak lain melanggar:

a. Pasal 4 berupa membuat perjanjian oligopoli;

b. Pasal 9 berupa membuat perjanjian pembagian wilayah;

c. Pasal 10 berupa membuat perjanjian pemboikotan;

d. Pasal 11 berupa membuat perjanjian kartel;

e. Pasal 12 berupa membuat perjanjian trust;

f. Pasal 13 berupa membuat perjanjian oligopsoni;

g. Pasal 14 berupa membuat perjanjian integrasi vertikal;

h. Pasal 16 berupa membuat perjanjian yang dilarang oleh pihak luar negeri;

i. Pasal 17 berupa melakukan kegiatan monopoli;

j. Pasal 18 berupa melakukan kegiatan monopsoni;

k. Pasal 19 berupa melakukan penguasaan pasar yang dilarang;

I. Pasal 25 berupa menyalahgunakan posisi dominan;

m. Pasal 27 berupa kepemilikan saham yang dilarang;

n. Pasal 28 berupa melakukan merger, akuisisi, dan konsolidasi yang dilarang;

2. Dapat dipidana sebagaimana dalam Pasal 48 ayat (2), apabila pelaku usaha dan atau pihak lain melanggar:

a. Pasal 5 s.d. 8 berupa penetapan harga yang dilarang;

b. Pasal 15 berupa perjanjian tertutup yang dilarang;

c. Pasal 20 berupa melakukan jual rugi yang dilarang;

d. Pasal 21 berupa melakukan kecurangan dalam menetapkan komponen harga barang;

e. Pasal 22 s.d. 24 berupa persengkongkolan yang dilarang;

f. Pasal 25 berupa penyalahgunaan posisi dominan;

3. Dapat dipidana sebagaimana dalam Pasal 48 ayat (3), apabila pelaku Jurnal Hukum KAIDAH 
usaha dan atau pihak lain melanggar Pasal 41 yaitu:

a. Tidak menyerahkan alat bukti yang diperlukan dalam penyelidikan dan atau pemeriksaan;

b. Menolak diperiksa, menolak memberikan informasi yang diperlukan dalam penyelidikan dan atau pemeriksaan, atau menghambat proses penyelidikan dan atau pemeriksaan.

Rumusan tindak pidana dalam Pasal 48 ayat (3) di atas sudah jelas, yaitu terhadap pelaku usaha dan atau pihak lain yang melanggar sebagaimana ketentuan Pasal 41, yaitu pada pokok mengenai perbuatan menghalangi/menghambat penyelidikan dan atau pemeriksaan di KPPU. Akan tetapi, berbeda dengan tindak pidana dalam Pasal 48 ayat (1) dan (2) di atas, apabila dirumuskan secara letterlijk maka akan menimbulkan ketidakjelasan. Contoh pada Pasal 48 ayat (1) jo. Pasal 11, yaitu perbuatan pelaku usaha dan atau pihak lain yang membuat perjanjian kartel dapat disebut sebagai tindak pidana/delik.

Pasal 11 UU No. 5 Tahun 19991999 mengatur mengenai pengertian kartel, yaitu pelaku usaha dilarang membuat perjanjian antara pesaingnya untuk memengaruhi harga dengan cara mengatur produksi dan/atau pemasaran suatu barang dan/atau jasa. Larangan ini menggunakan pendekatan rule of reason karena hanya berlaku apabila perjanjian kartel tersebut dapat mengakibatkan terjadinya monopoli dan/atau persaingan usaha tidak sehat. ${ }^{27}$ Perumusan kartel secara rule of reason oleh pembentuk Undang-undang No. 5 Tahun 1999 dapat diartikan pelaku usaha dapat membuat perjanjian dengan pelaku usaha pesaingnya yang bermaksud untuk mempengaruhi harga

${ }^{27}$ Mustafa Kamal Rokan, Hukum Persaingan Usaha: Teori dan Praktik di Indonesia, Rajagrafindo Persada, Jakarta, 2012, hal. 118. dengan mengatur produksi atau pemasaran suatu barang atau jasa asalkan alasannya dibenarkan dan tidak mengakibatkan terjadinya praktik monopoli dan persaingan usaha tidak sehat.

Penulis akan mengambil contoh kasus praktik kartel yang dilakukan oleh 6 produsen ban kendaraan roda empat di Indonesia yang tergabung dalam Asosiasi Perusahaan Ban Indonesia $(\mathrm{APBI})$. Kartel tersebut dilakukan antara sesama produsen ban di Indonesia. Praktik kartel yang dilakukan terkait produksi dan/atau pemasaran ban kendaraan bermotor roda empat kelas passenger car (penumpang) untuk ban Ring 13, Ring 14, Ring 15 dan Ring 16 periode 2009-2012 di wilayah Indonesia yang diproduksi dan dipasarkan oleh perusahaan ban yang tergabung dalam APBI. Enam produsen ban tersebut terbukti melakukan kartel selama periode 2009 2012. KPPU menemukan fakta dalam rapat presidium Asosiasi Pengusaha Ban Indonesia (APBI) dalam kurun waktu 2009 sampai dengan 2012 yang mengindikasikan adanya kesepakatan untuk menahan produksi. Perkara tersebut sudah diputus dalam ranah administrasi melalui Putusan KPPU Nomor 08/KPPU-1/2014 dengan amar putusan sebagai berikut:

1. Menyatakan bahwa Terlapor I, Terlapor II, Terlapor III, Terlapor IV, Terlapor V dan Terlapor VI, terbukti secara sah dan meyakinkan melanggar Pasal 11 UndangUndang Nomor 5 Tahun 1999.

2. Menghukum Terlapor I, Terlapor II, Terlapor III, Terlapor IV, Terlapor V dan Terlapor VI membayar denda sebesar $R p$ 25.000.000.000,00 (dua puluh lima miliar rupiah).

Para Terlapor mengajukan upaya hukum keberatan terhadap Putusan KPPU Nomor 08/KPPU-1/2014 tersebut ke Pengadilan Negeri Jakarta Pusat dengan Putusan Jurnal Hukum KAIDAH 
Perkara 70/Pdt.Sus-KPPU/2015/PN.Jkt.Pst yang pada pokoknya menguatkan Putusan KPPU dan mengubah besaran denda. Selanjutnya perkara tersebut diajukan upaya hukum kasasi dengan Putusan Mahkamah Agung Nomor 221K/pdt.Sus-KPPU/2016 yang pada pokoknya menguatkan Putusan Pengadilan Negeri tersebut dan menolak permohonan kasasi Para Pemohon yang artinya adalah kembali menguatkan Putusan KPPU. Para Terlapor kemudian mengajukan upaya hukum luar biasa melalui peninjauan kembai (PK) ke Mahkamah Agung melalui Putusan Nomor 167-PK/Pdt.Sus-KPPU/2017 tanggal 25 Januari 2017 dengan amar menolak permohonan peninjauan kembali dan menghukum Para Pemohon membayar biaya PK sebesar Rp 2.500.000,00 (dua juta lima ratus ribu rupiah). Dengan telah ditolaknya permohonan peninjauan kembali dari para pelaku usaha, maka Putusan KPPU No. 08/KPPU- I/2014 tentang pelanggaran Pasal 11 UU No. 5 Tahun 1999 dalam Industri Otomotif terkait Kartel Ban Kendaraan Bermotor Roda Empat telah berkekuatan hukum tetap (inkracht).

Uraian di atas apabila dilihat dari kewenangan KPPU dalam penegakan hukum administrasi UU No. 5 Tahun 1999 (vide: Pasal 36) dan upaya hukum terhadap penegakan hukum tersebut (vide: Pasal 4546), maka Asosiasi Perusahaan Ban Indonesia (APBI) telah terbukti melakukan pelanggaran Pasal 11 UU No. 5 Tahun 1999 berupa melakukan perjanjian praktik kartel dan terhadap pelaku usaha tersebut dijatuhkan hukuman tindakan administrasi sebagaimana dalam Pasal 47 UU No. 5 Tahun 1999. Akan tetapi, apakah perbuatan tersebut juga dapat dipidanakan, mengingat apabila merujuk pada ketentuan pidana Pasal
48 ayat (1) UU No. 5 Tahun 1999, yaitu "pelanggaran terhadap ketentuan Pasal 11 diancam pidana denda serendah-rendahnya Rp 25.000.000.000,00 (dua puluh lima miliar rupiah) dan setinggi-tingginya $R p$ 100.000.000.000,00 (seratus miliar rupiah), atau pidana kurungan pengganti denda selama-lamanya 6 (enam) bulan".

Vos berpendapat bahwa delik/tindak pidana dapat dibedakan menjadi sebagai berikut:

1. Delik tatbestandmassigkeit adalah perbuatan yang memenuhi unsur delik yang dirumuskan;

2. Delik wesenschaw adalah suatu perbuatan dikatakan telah memenuhi unsur delik tidak hanya karena perbuatan tersebut telah sesuai dengan rumusan delik tetapi perbuatan tersebut juga dimaksudkan oleh pembentuk undang-undang. ${ }^{28}$

Pasal 48 ayat (1) UU No. 5 Tahun 1999 dan perbuatan APBI yang melanggar Pasal 11 apabila dihubungkan secara letterlijk, maka terhadap perbuatan APBI yang membuat perjanjian kartel tersebut telah memenuhi/masuk ke dalam rumusan tindak pidana sebagaimana dalam Pasal 48 ayat (1) UU No. 5 Tahun 1999 di atas. Penulis berpendapat bahwa dengan melihat rumusan tindak pidana dalam Pasal 48 (1) dan (2) UU No. 5 Tahun 1999 secara letterlijk, maka akan menjadikan pasal tersebut sebagai delik tatbestandmassigkeit, yaitu apabila pelaku usaha melakukan perjanjian yang dilarang, kegiatan yang dilarang, atau posisi dominan sebagaimana dimaksud dalam UU No. 5 Tahun 1999, maka perbuatan tersebut barang tentu juga sekaligus merupakan tindak pidana dan diberikan sanksi pidana. Hal tersebut akan menciptakan ketidakpastian hukum, yaitu tidak ada batasan jelas kapan pelaku

\footnotetext{
${ }^{28}$ Eddy O.S. Hiariej, Prinsip-Prinsip Hukum ......Op.Cit., hal. 133.
} 


\section{Media Komunikasi dan Informasi Hukum dan Masyarakat}

usaha dapat diproses/ditindak melalui tindakan administrasi maupun diproses di ranah pidana.

Penulis berpendapat bahwa terhadap tindak pidana dalam Pasal 48 (1) dan (2) UU No. 5 Tahun 1999 harus dimaknai sebagai delik wesenschaw, yaitu suatu perbuatan dikatakan telah memenuhi unsur delik tidak hanya karena perbuatan tersebut telah sesuai dengan rumusan delik tetapi perbuatan tersebut juga dimaksudkan oleh pembentuk undang-undang. Oleh karena itu, untuk mengetahui maksud oleh pembentuk undangundang mengenai tindak pidana tersebut, maka perlu ada penafsiran yang didasarkan atas sejarah (historis) terbentuknya pasal tersebut.

Sudikno Mertokusumo berpendapat mengenai penafsiran historis, yaitu:

Apabila penafsiran peraturan tertentu didasarkan pada maksud atau tujuan pembentukan undang-undang peraturan tertentu tersebut dengan meneliti hasil pembicaraan dan dokumen di DPR yang mendahului terciptanya peraturan tertentu tersebut, maka disebut penafsiran historis menurut undang-undang. Maksud pembentuk undang-undang itu tampak dari hasil pembicaraan di DPR. Di sini yang dicari adalah maksud suatu peraturan seperti yang dikehendaki oleh pembentuk undang-undang. Kehendak membentuk undang-undanglah yang bersifat menentukan. Penafsiran ini disebut juga penafsiran subjektif kerena penafsiran dipengaruhi oleh pandangan subjektif dari pembentuk undangundang. ${ }^{29}$

Taufiequrochman Ruki selaku Anggota DPR dalam Rapat Panitia Kerja ke-8 Perancangan UU No. 5 Tahun 1999 tanggal 11 Januari 1999 berpendapat bahwa:

Apabila pelaku usaha yang telah diputuskan oleh KPPU melakukan pelanggaran atau melakukan praktek monopoli atau melakukan persaingan

${ }^{29}$ Sudikno Mertokusumo, Penemuan Hukum Sebuah Pengantar, Cahaya Atma Pustaka, Yogyakarta, 2014, hal.78-79. usaha tidak sehat, tidak melakukan keputusan KPPU sesuai dengan tenggang waktu yang diberikan dan tidak mengajukan keberatan ke pengadilan maka limpahkan saja perkara/kasus itu kepada penyidik untuk disidik sesuai dengan kewenangan yang dimiliki oleh penyidik. ${ }^{30}$

Muchtar selaku Sekjen Depperindag dalam agenda dan waktu rapat yang sama pada pokoknya sependapat dengan pendapat Taufiequrochman Ruki bahwa:

KPPU juga harus diberi wewenang untuk menjatuhkan sanksi denda administrasi kepada pelaku usaha yang dianggap melanggar. Hal ini tidak akan membingungkan karena ke proses pengadilan apabila putusan KPPU itu tidak dipatuhi dan pelaku usaha akan dikenakan denda pidana. Namun, apabila putusan KPPU sudah dipatuhi tentunya tidak akan berlanjut ke Pengadilan. ${ }^{31}$

Mardjono Reksodiputro dalam Rapat Dengar Pendapat Umum Perancangan UU No. 5 Tahun 1999 pada tanggal 20 November 1998 berpendapat bahwa:

Undang-undang ini ingin mengatur suatu cara melakukan menjalankan perusahaan perdagangan khususnya ingin mengatur cara melakukan persaingan yang sehat. Karena pengertian tentang persaingan yang sehat, kurang sehat, tidak sehat itu tidak mudah, maka dibentuk satu komisi. Komisi ini setelah menemukan adanya tidak pantas, dianggap tidak pantas memberikan, memutuskan adanya satu keadaan atau satu yang tidak pantas, itu memberikan suatu putusan pada dasarnya ada satu perintah dari Komisi itu untuk mengubah cara berbinisnya. Apabila hal ini tidak diindahkan, yang bersangkutan itu mengacuhkan hal ini dapat dilakukan tindakan-tindakan lanjutan. Apabila dia demikian serius menurut Komisi dan tetap tidak diacuhkan rekomendasi atau kesimpulan Komisi (putusan), dia tidak memperbaikinya, dibawa ke Pengadilan Pidana dan dijatuhkan dan dinyatakan bersalah oleh Hakim Pidana. ${ }^{32}$

${ }^{30}$ Risalah Rapat Proses Pembahasan Rancangan Undang-Undang No. 5 Tahun 1999.....Op.Cit., hal. 1207.

${ }^{31}$ Ibid., hal. 1211 dan 1213

${ }^{32}$ Ibid., hal. 375.

Jurnal Hukum KAIDAH 
Sudarto berpendapat bahwa perumusan dari perbuatan yang dapat dipidana itu berupa suatu larangan atau perintah untuk berbuat atau tidak berbuat sesuatu. Perintah itu bisa disebut norma atau pelanggaran norma. ${ }^{33}$ Noyon dan Langemeijer senada dengan pendapat Sudarto bahwa "perbuatan yang dimaksud dapat bersifat positif dan negatif. Perbuatan bersifat positif berarti melakukan sesuatu, dengan perbuatan bersifat negatif mengandung arti tidak melakukan sesuatu. Fraser Sampson berpendapat bahwa "tidak melakukan apa yang menjadi kewajibannya atau tidak melakukan sesuatu yang seharusnya dilakukan dikenal dengan omissions. ${ }^{34}$

\section{Pendapat Taufiequrochman Ruki,} Muchtar, Mardjono Reksodiputro, Sudarto, Noyon, Langemeijer, dan Fraser Sampson di atas apabila dihubungkan dengan ketentuan Pasal 44 ayat (4) dan Pasal 48 ayat (1) dan (2) UU No. 5 Tahun 1999, maka diperoleh makna bahwa pelaku usaha dan atau pihak lain baru dapat dikenakan pidana pokok sebagaimana Pasal 48 ayat (1) dan (2) UU No. 5 Tahun 1999 apabila pelaku usaha dan atau pihak lain tersebut tidak melaksanakan apa yang menjadi kewajibannya sebagaimana dalam Putusan KPPU yang telah BHT. Kewajiban pelaku usaha dan atau pihak lain tersebut berupa menjalankan sanksi/tindakan administrasi sebagaimana Pasal 47 UU No. 5 Tahun 1999 yang dijatuhkan oleh KPPU atas pelanggaran administrasi UU No. 5 Tahun 1999. Hal tersebut menandakan bahwa dalam penegakan hukum pidana terhadap pelanggaran UU No. 5 Tahun 1999 bersifat ultimum remidium, yaitu apabila tindakan/sanksi administrasi KPPU tidak

\footnotetext{
${ }^{33}$ Sudarto, Hukum Pidana.......Op.Cit., hal. 88-89.

${ }^{34}$ Eddy O.S. Hiariej, Prinsip-Prinsip Hukum ......Op.Cit., hal. 122.
}

berfungsi, maka barulah dapat menggunakan peranan sanksi pidana untuk penegakan hukum terhadap praktik monopoli dan persaingan usaha tidak sehat.

Dengan demikian berdasarkan uraian di atas, maka rumusan tindak pidana dalam Pasal 48 ayat (1) dan (2) UU No. 5 Tahun 1999 dapat dimaksudkan sebagai berikut:

1. Pasal 48 ayat (1) bahwa "pelaku usaha dan atau pihak lain yang tidak melaksanakan Putusan KPPU sudah BHT yang terhadapnya terbukti:

a. membuat perjanjian oligopoli sebagaimana Pasal 4;

b. membuat perjanjian pembagian wilayah sebagaimana Pasal 9;

c. membuat perjanjian pemboikotan sebagaimana Pasal 10;

d. membuat perjanjian kartel sebagaimana Pasal 11;

e. membuat perjanjian trust sebagaimana Pasal 12.

f. membuat perjanjian oligopsoni sebagaimana Pasal 13;

g. membuat perjanjian integrasi vertikal sebagaimana Pasal 14;

h. membuat perjanjian yang dilarang oleh pihak luar negeri sebagaimana Pasal 16;

i. melakukan kegiatan monopoli sebagaimana Pasal 17;

j. melakukan kegiatan monopsoni sebagaimana Pasal 18;

k. melakukan penguasaan pasar yang dilarang sebagaimana Pasal 19;

I. menyalahgunakan posisi dominan sebagaimana Pasal 25;

m. memiliki saham yang dilarang sebagaimana Pasal 27

n. melakukan merger, akuisisi, dan konsolidasi yang dilarang sebagaimana Pasal 28.

diancam pidana denda serendah-rendahnya Rp 25.000.000.000 (dua puluh lima miliar rupiah) dan setinggi-tingginya $\mathrm{Rp}$ 100.000.000.000 (seratus miliar rupiah) atau pidana kurungan pengganti denda selamalamanya 6 (enam) bulan".

2. Pasal 48 ayat (2) bahwa "pelaku usaha dan atau pihak lain yang tidak melaksanakan Putusan KPPU sudah BHT yang terhadapnya terbukti:

a. melakukan penetapan harga yang dilarang sebagaimana Pasal 5 s.d. 8;

b. melakukan perjanjian tertutup yang dilarang sebagaimana Pasal 15;

c. melakukan jual rugi yang dilarang sebagaimana Pasal 20; 
Media Komunikasi dan Informasi Hukum dan Masyarakat

d. melakukan kecurangan dalam menetapkan komponen harga barang sebagaimana Pasal 21;

e. melakukan persengkongkolan yang dilarang sebagaimana Pasal 22 s.d. 24;

f. melakukan penyalahgunaan posisi dominan sebagaimana Pasal 25 ;

diancam pidana denda serendahrendahnya $\mathrm{Rp}$ 5.000.000.000 (lima miliar rupiah) dan setinggi-tingginya $R p$ 25.000.000.000 (dua puluh lima miliar rupiah) atau pidana kurungan pengganti denda selama-lamanya 5 (lima) bulan".

\section{KESIMPULAN DAN SARAN}

\section{A. Kesimpulan}

Adapun kesimpulan dalam tulisan ini, yaitu kebijakan formulasi tindak pidana terhadap pelaku usaha yang tidak melaksanakan putusan KPPU yang BHT diatur dalam Pasal 48 ayat (1) dan (2) UU No. 5 Tahun 1999 yang dimaksudkan sebagai delik wesenschaw. Dalam hal ini perbuatan pelaku usaha dikatakan telah memenuhi unsur tindak pidana tidak hanya karena perbuatan tersebut telah sesuai dengan rumusan tindak pidana tetapi perbuatan tersebut juga dimaksudkan oleh pembentuk undang-undang, bahwa pelaku usaha dapat dijatuhi pidana apabila tidak melaksanakan putusan KPPU sudah BHT berupa sanksi/tindakan administrasi atas pelanggaran administrasi UU No. 5 Tahun 1999. Hal tersebut menandakan penjatuhan pidana dalam Pasal 48 ayat (1) dan (2) UU No. 5 Tahun 1999 bersifat ultimum remidium (sarana terakhir).

\section{B. Saran}

Saran dalam tulisan ini, yaitu pembentuk undang-undang dalam memformulasikan suatu tindak pidana dalam undang-undang harus sejelas mungkin agar tidak menimbulkan multitafsir dan ketidakpastian hukum.

\section{DAFTAR PUSTAKA}

A. Buku:

Adami Chazawi. Pelajaran Hukum Pidana, Jakarta: Rajagrafindo, 2002.

Barda Nawawi Arief, Bunga Rampai Kebijakan Hukum Pidana, Bandung: Citra Aditya Bakti, 2002.

Barda Nawawi Arief, Kapita Selekta Hukum Pidana, Bandung: Citra Aditya Bakti, 2003.

DPR RI, Risalah Rapat Proses Pembahasan Rancangan Undang-Undang tentang Larangan Praktik Monopoli dan Persaingan Usaha Tidak Sehat, Jakarta: Sekretariat Jenderal DPR RI, 1999.

Eddy O.S. Hiariej, Prinsip-Prinsip Hukum Pidana, Yogyakarta: Cahaya Atma Pustaka, 2016.

Hambali Thalib, Sanksi Pemidanaan dalam Konflik Pertanahan, Jakarta: Kencana Prenada Media Group, 2012.

Komisi Pengawas Persaingan Usaha, Laporan Tahunan KPPU Tahun 2008.

Muladi, Proyeksi Hukum Pidana Materiil Indonesia di Masa Datang, Naskah Pidato Pengukuhan diucapkan pada Peresmian Penerimaan Jabatan Guru Besar dalam IImu Hukum pada Fakultas Hukum Universitas Diponegoro, Semarang, 1990.

Muladi, Kapita Selekta Sistem Peradilan Pidana, Semarang: Badan Penerbit UNDIP, 1995.

Muladi dan Barda Nawawi Arief, Teori-Teori dan Kebijakan Pidana, Bandung: Alumni, 1998.

Mustafa Kamal Rokan, Hukum Persaingan Usaha: Teori dan Praktik di Indonesia, Jakarta: Rajagrafindo Persada, 2012.

Soedjono Dirdjosisworo, Pemeriksaan Pendahuluan menurut KUHAP, Bandung: Alumni, 1982.

Sudarto, Hukum Pidana I, Semarang: Yayasan Sudarto, 2013.

Sudarto, Kapita Selekta Hukum Pidana, Bandung: Alumni, 1986. 
Sudikno Mertokusumo, Penemuan Hukum

Sebuah Pengantar, Yogyakarta: Cahaya Atma Pustaka, 2014.

Yudi Hidayat, Bahan Paparan oleh Komisi

Pengawas Persaingan Usaha disampaikan dalam Diklat III Program Pendidikan dan Pelatihan Calon Hakim Terpadu Angkatan III Gel. I tanggal 4 September 2019 di Badiklat Litbang Kumdil Mahkamah Agung, Megamendung.

\section{B. Artikel Jurnal:}

Eman Sulaeman, Kebijakan Penggunaan Sanksi Pidana dalam PerundangUndangan Hukum Administrasi. Wahana Akademika IAIN Walisongo Semarang, 1(1), 135-148, 2014, doi: http://dx.doi.org/10.21580/wa.v1i1.806.

\section{Artikel Internet:}

Guntur Syahputra Saragih. Update Eksekusi Putusan KPPU, tersedia pada http://www.kppu.go.id/id//olog/2019/07/up date-eksekusi-putusan-kppu/, diakses pada 6 September 2019.

Mudzakkir. Mempersoalkan Sanksi Pidana dalam Hukum Persaingan Usaha: Pengaturan sanksi pidana di dalam UU Anti Monopoli dinilai tak memenuhi ketentuan pidana, tersedia pada https://www.hukumonline.com/berita/ba ca/hol21865/mempersoalkansanksi-pidana-dalam-hukumpersaingan-usahal 